\title{
A Study on "Experiential" English Teaching Mode of Higher Vocational Colleges
}

\author{
Ling $\mathrm{Xu}$ \\ Tianjin Vocational Institute, Tianjin, 300410, China
}

Keywords: Higher vocational colleges, "Experiential" English teaching, Value

\begin{abstract}
The development of social economy has raised many requirements on the development of higher vocational education, and a problem to be resolved in higher vocational education is how to cultivate talents with practical application ability; meanwhile, English is a global language, and the English teaching of higher vocational colleges cannot be ignored during talent cultivation. Considering the characteristics of English teaching in higher vocational colleges and the needs of cultivating higher vocational talents, the experiential English teaching becomes a teaching mode actively explored by English teachers in higher vocational colleges. This paper firstly analyzes the problems existing in English teaching of higher vocational colleges as well as the meaning and significance of experiential English teaching, and then provides suggestions about carrying out the experiential English teaching in higher vocational education.
\end{abstract}

\section{Introduction}

The position of English is still not changed among the global languages, and it still plays a very important role in the global political, diplomatic and technical communication. Meanwhile, many different kinds of talents are still needed for the social development, and skilled professionals are eagerly required for the development of economy and society, while English is an indispensable tool for those top-level skilled talents. In the face of such demands, how to cultivate skilled talents with high English attainment is a brand-new and very important task for English teaching in higher vocational colleges. Relevant educational department of the state proposed that the higher vocational English shall not only require a solid English foundation, but also pay attention to cultivating the practical ability of language application; according to the current situation of English teaching in higher vocational colleges, the experiential English teaching has become a teaching mode actively explored in English teaching of higher vocational colleges, to gradually achieve the transformation from traditional English teaching mode to experiential English teaching mode.

The experiential English teaching proposes to give play to the function of students themselves and carry out the English teaching with the life experience and existing knowledge of students themselves, and to encourage students to participate in various activities and actively accomplish the English learning task; the experiential English teaching is consistent with the skilled-based education guidance in teaching theories of higher vocational colleges. Theoretically, the existence of experiential English teaching is relative to the experiential learning. The psychologist Kelly proposed the "personal construct" theory. Different learners apply different construct methods to accomplish their learning tasks, and different construct methods have different influence on the learning processes and methods of the learners. Based on this theory, teachers shall pay high attention to observing each learner's learning method and style and giving play to learner's own characteristics for experience and comprehension, so as to make them effectively obtain the knowledge.

As the sources and quality of students are different, the higher vocational English teaching is also different from the undergraduate English teaching and shall pay more attention to the experiential English teaching, to make higher vocational college students who have a weak foundation stimulate their interest of independent English learning and actively perform the meaning construction of the knowledge learned and finally become high-quality skilled talents. 


\section{Problems in English teaching of higher vocational colleges}

Compared with students of undergraduate universities, the students of higher vocational colleges are significantly different in the aspect of English ability. In general, students in higher vocational colleges have a poor basic English knowledge, need to enhance their quantity of vocabularies, and have difficulties in English application such as listening, speaking, reading, writing and translation; generally speaking, higher vocational students' English learning is still in the cognitive level and has not reached the language communication level yet, let alone form the English logic expression mode. More importantly, students in higher vocational colleges have lost their interest in English learning as their English learning is always in a low level.

The experiential English teaching advocates the situational \& communicative teaching, however, it can be carried out in higher vocational colleges only after students' own problems are resolved. To explore the experiential English teaching suitable for students in higher vocational colleges, it is required to gradually eliminate the mental stress of students in higher vocational colleges and create foreign language scene activities for the experiential English teaching.

Besides, the English teaching in higher vocational colleges is conducted in the form of large class English teaching, which is caused by the unbalanced proportion between English teachers and students in higher vocational colleges. Meanwhile, the limited knowledge level and ability of students in higher vocational colleges result in unsmooth implementation of English teachers' teaching plans, let alone perform the experiential English teaching that emphasizes individual activities. Various difficulties need to be overcome to implement the experiential English teaching process in higher vocational colleges, which proposes an important research subject for English teachers in higher vocational colleges.

The basic requirements for English course teaching in higher vocational colleges are to take the practical application as the main purpose and to meet the needs of skilled talent posts. However, at present, examination is the main assessment method in English teaching of higher vocational colleges, which fails to meet the basic requirements of English teaching in higher vocational colleges.

\section{Meaning and significance of experiential English teaching mode in higher vocational colleges}

The experiential English teaching encourages students to learn in practice and centers on students, who will learn independently in this process to achieve self-experience and self-education. This teaching mode is the transformation from imparting mode to experiential mode. The experiential English teaching can keep students in a real language learning environment with a strong information input, so as to facilitate students' language output and cultivate their independence and practical language application ability. The English teaching in higher vocational college cannot be separated from the goal of talent cultivation and the teaching philosophy of paying attention to skill cultivation in higher vocational colleges. The teaching in higher vocational colleges advocates the quality-oriented education and vocational education, and the experiential English teaching centers on participants and emphasizes their experience and feeling, to actively obtain the English knowledge and skills about realistic scenes and environment. The experiential English teaching can embody the professional knowledge of higher vocational colleges and make students not only master the English knowledge, but also enhance their professional English application skills in the teaching process.

English teachers of higher vocational colleges set tasks and goals for students in the three aspects of experiential cognition, skill training and emotional inspiration; the language competence is not obtained by accumulating the knowledge imparted by English teachers, but is gradually formed by a lot of contact and understanding as time goes on; it can be obtained only by learning, full understanding and input.

The experiential English teaching mode must be based on students in higher vocational colleges, pay high attention to personalities of students in higher vocational colleges and integrate the knowledge impartation with the ability cultivation, to gradually form the experiential English teaching mode that centers on students and in which students actively participate. Students in higher 
vocational colleges have unbounded personalities, and the experiential English teaching mode centering on students in higher vocational colleges will form spontaneously in the process of paying attention to their personalities, to effectively facilitate the gradual perfection of the experiential English teaching; in this process, the emotion communication between teachers and students will also enhance the self-confidence of students in higher vocational colleges. Compared with the traditional English teaching mode, the experiential English teaching mode more aligned with the characteristics of students in higher vocational colleges. Finally, as the students in higher vocational colleges are different in the English level, the experiential English teaching shall be performed step by step based on the English level of students, so as to give consideration to those students who have a low English level and those who are reticent, make them actively participate in experiential English teaching activities and constantly improve their English level.

The experiential English teaching requires teachers in higher vocational colleges to create scenes that shall intentionally merge important English knowledge points. In these scenes, students in higher vocational colleges can really experience the language and understand the knowledge points, which will stimulate their strong interest in English learning and make them actively improve their abilities in practical English application. Furthermore, whether the experiential English teaching can be performed smoothly is closely related to teachers' teaching level. Cultivating double-qualified teachers is a requirement for development of higher vocational colleges; double-qualified teachers shall not only have rich work experience, solid foundation of professional knowledge and practical work skills, but also have certain teaching ability. As long as English teachers in higher vocational colleges meet the aforesaid requirements, they can become skilled creators of practical language scenes and excellent assessors of learning effect. Cultivating English teachers with good quality and skills in higher vocational colleges will play a positive role in experiential English teaching in higher vocational colleges.

\section{Implementation of experiential English teaching mode in higher vocational colleges}

The experiential teaching is generated based on the experiential learning, and the experiential learning is the learning based on experience; this learning process is divided into four cycle steps: first, carry out the experience, feeling and understanding in elaborately designed scenes; second, observe, think about and even summarize such experience so as to think about the feeling and understanding in the abstract level; third, think about them in a more universal range and raise them to theories; fourth, apply the summaries and theories into practice and prepare for the next practice so as to effectively experience the next step of learning process; finally, such step-by-step experience and thinking form the experiential learning cycle that is the vigor source of learners' continuous leaning.

The experiential teaching requires the scene creation and cooperative learning in the teaching link; on this basis, students themselves finally achieve the knowledge construction. The experiential teaching mode facilitates students' self-playing in the process and obtainment of a lot of happiness and satisfaction, and further make students actively perform the experiential learning and quickly master the knowledge. In the process of experience, learners shall personally join in the activities, feel the experience and understanding and obtain new knowledge by means of such experience and understanding. The English course assessment in higher vocational colleges is still dominated by basic summative assessment, which is very difficult to adapt to the experiential English teaching; the experiential English teaching attaches importance to learners' real experience in the learning process, the obtainment of language knowledge, and the process of experience. Meanwhile, such class assessment makes students completely involved in the scene experience in class. To accomplish such experience, English teachers in higher vocational colleges shall pay attention to each student's characteristics in the process of scene setting, encourage those students with gradual progress, give full play to students' independence and allow them to perform the independent experiential learning.

In the process of teaching, teachers need to constantly explore new knowledge and methods. In the higher vocational education, the function of English teachers in higher vocational colleges cannot be ignored. As a new teaching method, the experiential English teaching provides English teachers in 
higher vocational colleges with a platform of teacher-student mutual improvement. In the process of scene creation, English teachers in higher vocational colleges need to mobilize all of their knowledge, experience and vigor for careful design, make proper adjustments based on characteristics of different students, and find learning contents and materials appropriate for their students, which will greatly improve the abilities of English teachers in higher vocational colleges. Besides, English teachers in higher vocational colleges shall adequately observe each student's psychological state and fully mobilize students in the experience.

Besides, attention shall be also paid to the function of network platform. (1) Utilize the network platform to achieve the teacher-student interaction before the course learning. In the process of implementing the experiential English teaching, Teachers need to regard students as the main object and center of the teaching process and strengthen the concern about and the understanding of students. Thus, before starting the teaching class, teachers may utilize the network teaching platform to enter the discussion link of the course and actively raise a topic, so as to understand students' opinions and expectations on classroom English teaching as well as the assessment methods in the process of discussion. In this way, students can participate in the teacher's teaching process and the traditional passive learning can be transformed into active learning. (2) Utilize the network platform to achieve the scene creation in the process of course learning. In the context of network teaching platform, students can achieve the independent learning and scene experience. With this platform, students can select suitable learning contents and methods based on their own needs, abilities and interest, such as selecting some recreational videos to train their listening and reading, achieve the experience of English learning, and obtain relevant knowledge. Students can independently decide their own learning contents, time and methods, search for more resources and materials on the network platform, provide other students with more learning perspectives by classroom presentation, and really experience the practical English application. (3) Utilize the network platform to digest the knowledge and obtain the experience after the course learning. With the application of network platform, students can cultivate their own spirit of exploration, attitude of independent learning, and sense of learning responsibility by means of such tentative learning. Besides, the network teaching platform has also constructed many learning areas for students, including online tutoring, and question answering and discussion, can allow students to learn more contents that are not got in class and to get the teacher's guidance, and will increase the communication between students and teachers.

English teaching in higher vocational colleges is the same as other professional courses; they adopt the teaching mode that takes projects as driving force and centers on vocational activities, highlight the operational ability and vocational quality in practice, and are supported by theoretical knowledge impartation. In the process of experiential English teaching, it is required to create different scenes for students of different majors, to allow them to experience the language learning in career life and improve their English application ability in the process of constant reflection.

\section{Conclusion}

The goal of higher vocational education is to cultivate high-level skilled talents. To implement this teaching requirement, the English teaching in higher vocational colleges needs to explore a new talent cultivation mode. The combination of experiential English teaching theory and English teaching characteristics in higher vocational colleges has provided English students in higher vocational colleges with a new exploration and practice direction. In the practice of experiential English teaching, English teachers in higher vocational colleges play an important role in the aspects of giving full play to students' enthusiasm, scene creation, and stimulating students' experience. They are not only the students' guide in experiential English teaching, but also the explorers of experiential English teaching mode. The theoretical exploration of experiential English teaching by English teachers of higher vocational colleges has greatly promoted the development of English teaching and laid a solid foundation for cultivating high-level skilled talents. 


\section{Acknowledgments}

This paper is the subject of Tianjin Tertiary Technical and Vocational Education Research Association of in 2014; subject name: Empirical Research on "Experiential" English Teaching in Higher Vocational Colleges; subject number: XIV 499.

\section{References}

[1] Ye Yisheng and Zhang Donglian, Theoretical Exploration of Experiential English Teaching in the EFL Context. Teaching and Management (theory version), 2014, (9): 143-146.

[2] Hong Pingting, Application of Experiential Culture Teaching Mode in English Classes of Higher Vocational Colleges. Campus English (late of the month), 2014 (11): 72-73.

[3] Meng Lijun, Utilization of Experiential Teaching Mode to Enhance English Practice Abilities of Students in Higher Vocational Colleges. Journal of Tianjin Sino-German Vocational Technical College, 2014, (5): 25-26.

[4] Lu Lei, Application of Experiential English Teaching in Higher Vocational Colleges. Ability and Wisdom, 2014, (36): 112-112.

[5] Xia Chuan. A Brief Analysis on Problems and Countermeasures of English Teacher Management in Higher Vocational Education.//Proceedings of the Third international conference on education management science and engineering.2010:1004-1010. 